\title{
Differences in blood pressure according to physical fitness and body mass in a sample of Mexican schoolchildren
}

\author{
César I. Ayala-Guzmán, Lilia G. Jiménez Cruz y Luis Ortiz-Hernández* \\ Departamento de Atención a la Salud, Laboratorio de Nutrición y Actividad Física, Universidad Autónoma Metropolitana (unidad Xochimilco), Ciudad \\ de México, México
}

\begin{abstract}
Background: Physical fitness is the ability to perform activities of daily living without excessive fatigue. The potential protective role of fitness against high blood pressure in childhood is relevant to diminish the risk of hypertension in adulthood. A negative association between cardiorespiratory fitness (CRF) and hypertension has been found in the pediatric population. However, the role of body mass as a confounding variable of this association has not been evaluated. This study aimed to analyze whether the association between fitness and blood pressure in Mexican schoolchildren is independent of body mass. Methods: A cross-sectional study was conducted with a sample of 1010 children (574 females and 436 males) aged 9-12 years (mean age $=10.3 \pm 0.9$ years) from 13 elementary schools in Mexico City. Fitness was evaluated with tests from the FitnessGram ${ }^{\circledR}$ battery. Z-scores of body mass index (BMI)-for-age and height-for-age were estimated. Results: Low fitness showed a high prevalence (from $45.8 \%$ for trunk lift to $77.5 \%$ for push-ups). Children with poor CRF (assessed by the 20-m progressive aerobic cardiovascular endurance run test) and upper body strength (assessed by push-ups) showed a higher probability of hypertension $(p<0.05)$. However, these differences disappeared after adjusting for BMI. Conclusions: After considering the body mass, cardiorespiratory and musculoskeletal fitness were not independent predictors of blood pressure.
\end{abstract}

Key words: Cardiorespiratory fitness. Body mass index. Blood pressure. Muscular fitness. Mexico.

\section{Diferencias en la presión sanguínea de acuerdo con la condición física y masa corporal en una muestra de escolares mexicanos}

\section{Resumen}

Introducción: La condición física es la habilidad de realizar actividades de la vida diaria sin fatiga excesiva. El potencial papel protector de una buena condición física contra la presión arterial elevada es relevante, ya que, si no se atiende, esta elevación en la presión arterial comúnmente conduce a hipertensión en la vida adulta. Se ha documentado una asociación negativa entre la condición cardiorrespiratoria con la hipertensión de la población pediátrica. Sin embargo, no se ha evaluado el papel de la masa corporal como una variable de confusión de esta asociación. El objetivo de este estudio fue evaluar si la asociación entre la condición física y la presión sanguínea es independiente de la masa corporal en escolares mexicanos. Métodos: Estudio transversal con una muestra de 1010 escolares (574 de sexo femenino y 436 de sexo masculino) de 9 a 12 años (edad prome-

Correspondencia:

*Luis Ortiz-Hernández

E-mail: lortiz@correo.xoc.uam.mx
Fecha de recepción: 27-08-2019 Fecha de aceptación: 02-12-2019 DOI: 10.24875/BMHIM.19000139
Disponible en internet: 17-02-2020 Bol Med Hosp Infant Mex. 2020;77(1):15-22 www.bmhim.com 1665-1146/@ 2019 Hospital Infantil de México Federico Gómez. Publicado por Permanyer. Este es un artículo open access bajo la licencia CC BY-NC-ND (http://creativecommons.org/licenses/by-nc-nd/4.0/). 
dio $=10.3 \pm 0.9$ años) de 13 escuelas de primaria de la Ciudad de México. La condición física se evaluó con la batería FitnessGram $^{\circledR}$. Se estimaron puntuaciones $Z$ del índice de masa corporal (IMC) para la edad. Resultados: La prevalencia de baja condición física fue alta (de $45.8 \%$ en la prueba de levantamiento de tronco a $77.5 \%$ en la prueba de lagartijas). Los escolares con baja condición cardiorrespiratoria (evaluada con la carrera progresiva de resistencia cardiovascular aeróbica de $20 \mathrm{~m}$ ) y fuerza superior del cuerpo (evaluada con la prueba de lagartijas) mostraron una mayor probabilidad de presentar hipertensión $(p<0.05)$. Sin embargo, estas diferencias desaparecieron al ajustar por el IMC. Conclusiones: Después de considerar la masa corporal, la condición cardiorrespiratoria y musculoesquelética no son predictores independientes de la presión sanguínea.

Palabras clave: Condición cardiorrespiratoria. Índice de masa corporal. Presión sanguínea condición musculoesquelética. México.

\section{Introduction}

Physical fitness is a set of attributes that people acquire or improve and is related to the ability to perform activities of daily living without excessive fatigue. The components of health-related fitness include cardiorespiratory fitness (CRF), musculoskeletal fitness, balance, and body composition. The potential protective role of fitness against high blood pressure in childhood is a relevant topic, as high blood pressure in childhood commonly leads to hypertension in adulthood $^{1}$, which in turn is a risk factor for coronary heart disease, heart failure, and stroke ${ }^{2}$.

Most research in pediatric populations has documented a negative association between CRF and hypertension ${ }^{3-5}$. In a systematic review ${ }^{6}$ of 20 longitudinal studies, CRF in childhood and adolescence was a predictor of cardiovascular disease risk factors (e.g., abnormal blood lipids or high blood pressure), metabolic syndrome, and arterial stiffness later in life. One limitation of this type of research is that, in most cases $^{3,4}$, the potential role of body mass as a confounding variable of the association between fitness and blood pressure has not been considered. Only one study has performed this adjustment ${ }^{5}$. The confounding role of body mass is produced by its negative relationship with $\mathrm{CRF}^{7,8}$ and its positive association with blood pressure ${ }^{3,9,10}$. The clinical relevance of making the distinction between the effect of CRF and body mass on blood pressure is to collect information to guide individuals for the prevention and reduction of high blood pressure risk. In other words, if the CRF has an independent effect on blood pressure, it should be a priority to intensify CRF to promote healthy blood pressure. In contrast, if the effect disappears after the adjustment by body mass index (BMI), the attention should be focused on preventing excessive weight gain.

In the pediatric population, the effects of other components of fitness (such as flexibility and muscular fitness) on blood pressure have been less studied. For example, there is less and inconclusive evidence ${ }^{6}$ about the relationship between muscular strength and cardiovascular risk factors (e.g., systolic blood pressure or blood lipids). In a review, only five longitudinal studies analyzed this association; in two of them, muscular strength was not associated with systolic or diastolic blood pressure, and the correlation between the neuromotor fitness index and the systolic and diastolic blood pressure was positive ${ }^{6}$. In another study, the association of strength with systolic blood pressure was negative.

More research is necessary to identify the factors that determine blood pressure in childhood, especially in children from middle-income countries, as they are exposed to a different socioeconomic environment and have distinct genetic characteristics from those in high-income countries. Therefore, the objective of this study was to evaluate whether the association between fitness and blood pressure in Mexican schoolchildren was independent of body mass.

\section{Methods}

A cross-sectional design was conducted with a convenience sample of children aged 9-12 years from 13 elementary schools in Mexico City. Before the study, an informed consent form was signed by parents or guardians and written assent from children was obtained. Fieldwork was conducted between June 2011 and February 2012. The project was approved by the Divisional Council of Biological Sciences and Health of the Universidad Autónoma Metropolitana, Unidad Xochimilco.

The sample size was estimated with an expected prevalence of hypertension of $22 \%$ and an odds ratio (OR) of 1.75 with the Epidat software ${ }^{11,12}$. Although previous research had reported an OR of 2.00 or higher ${ }^{4}$, a conservative estimate was used for this study because, in past studies, a few variables were considered as confounders and not included as covariates in 
the regression models. With these parameters, an estimated sample size of 915 participants was obtained. After fieldwork and database cleaning, the sample consisted of 1010 participants.

Fitness was evaluated using the FitnessGram ${ }^{\circledR}$ battery procedures developed by the Cooper Institute. The procedures and validity of the tests have been described elsewhere ${ }^{13}$. The research assistants received training, and pilot tests were conducted prior to fieldwork to ensure that they followed the procedures. The fitness components assessed in this study were as follows:

a.CRF. The number of laps in the $20-\mathrm{m}$ progressive aerobic cardiovascular endurance run test was recorded. Maximal aerobic capacity $\left(\mathrm{VO}_{2 \max }\right)$ was estimated using the Mahar equation ${ }^{14}$.

b. Muscular strength and endurance. The number of curl-ups (which is a proxy for core strength), pushups (upper body strength), and trunk lifts (trunk extensor strength) was documented.

c. Flexibility. The back-saver, sit-and-reach, and shoulder stretch tests were used to measure the flexibility of the back, legs, and shoulders, respectively.

The recorded audio from the FitnessGram ${ }^{\circledR}$ battery was used to instruct children to follow the pace in all tests and they were encouraged to perform their maximal effort. Due to the sex- and age-related differences in fitness, specific standards for these variables should be used to classify the fitness level of children. The criteria of the California Department of Education ${ }^{15}$ were used to classify this fitness level. More research has been done about the effects of CRF on health. Therefore, this dimension of physical fitness can be categorized in three levels: healthy zone (minimal disease risk), needs improvement (subject should be encouraged to increase his/her fitness because there is moderate risk of disease), and needs improvement-health risk (there is high risk of disease risk and subjects should be cautioned to improve her/his fitness) $^{13}$. For the rest of the fitness indicators, only two categories are described: a healthy zone and needs improvement.

Resting blood pressure was measured using OMRON digital Baumanometer (models HEM 781 IT and 705 IT), which has been previously validated in children and adolescents $^{16}$. To measure blood pressure, standardized procedures were followed: children were seated quietly for 5 min with their back supported, their feet on the floor, and their right arm supported, with the cubital fossa at heart level ${ }^{17}$. Pediatric cuffs of different sizes were used according to the arm circumference of each child. Blood pressure measurement was repeated with the same monitor when the participants had values higher than 120/80 mmHg because the American guidelines ${ }^{17}$ consider this level as pre-hypertension and it is more convenient for the fieldwork.

For data analysis, children were classified as having hypertension if their blood pressure was > percentile 95 for sex, age, and height of the American reference ${ }^{17}$. The height of the participants was classified according to the 2000 Centers for Disease Control and Prevention Growth $\mathrm{Charts}^{18}$. Three variables were constructed: isolated systolic hypertension (i.e., systolic blood pressure > percentile 95 but diastolic blood pressure < percentile 95), isolated diastolic hypertension (elevated diastolic blood pressure but normal systolic blood pressure), and systolic-diastolic hypertension (raised systolic or diastolic blood pressure or both).

Nutritional status was assessed by anthropometric measures (weight, height, and sitting height), which was obtained following standardized measurement techniques ${ }^{19}$. Observers were trained and standardized before the study. The Z-scores of BMI-for-age and height-for-age were estimated using the World Health Organization references ${ }^{20}$. Low height was defined as a Z-score of height-for-age $\leq-2.00$ standard deviation (SD) and normal height as a Z-score $\geq-1.99$ SD. Three categories were defined according to the Z-score of BMI-for-age: normal weight ( $\leq 0.99 \mathrm{SD})$, overweight (1.00-1.99 SD), and obesity ( $\geq 2.00 \mathrm{SD}$ ).

Statistical analysis was conducted using SPSS version 21 (Chicago, IL). Descriptive statistics of anthropometric characteristics (Table 1) and physical fitness (Table 2) were estimated. Bivariate analyses were performed to identify differences in anthropometric characteristics according to hypertension classification (Table 1), hypertension rates according to fitness level (Table 3), or differences in fitness according to BMI-forage (Table 4). For categorical variables, Chi-square tests were performed to determine the differences between groups, and for continuous variables, Student's t-test. Subsequent analyses were performed only for variables with statistically significant differences between groups.

Logistic regression models were estimated to determine whether the association of fitness with blood pressure was independent of BMI-for-age (Table 5). In the crude models, the blood pressure categories were introduced as dependent variables and fitness indicators as independent variables. Subsequently, for each dimension of fitness, two models were estimated: model $A$ was adjusted by sex and age while model $B$ was adjusted by the same covariates and BMI-for-age. 
Table 1. Anthropometric characteristics of a sample of Mexican schoolchildren and differences by blood pressure

\begin{tabular}{|c|c|c|c|c|}
\hline & \multicolumn{2}{|c|}{ Overall sample } & \multicolumn{2}{|c|}{ Differences by blood pressure } \\
\hline & $\mathbf{n}$ & $\%$ & Normal (\%) & Hypertension (\%) \\
\hline $\begin{array}{l}\text { Sex } \\
\text { Males } \\
\text { Females }\end{array}$ & $\begin{array}{l}436 \\
574\end{array}$ & $\begin{array}{l}43.2 \\
56.8\end{array}$ & $\begin{array}{l}42.7 \\
57.3\end{array}$ & $\begin{array}{l}44.7 \\
55.3\end{array}$ \\
\hline $\begin{array}{l}\text { BMI-for-age (Z-score) } \\
\text { Low weight }(\leq-2.0) \\
\text { Normal }(-1.9-0.9) \\
\text { Overweight }(1.0-1.9) \\
\text { Obesity }(\geq 2.0)\end{array}$ & $\begin{array}{c}22 \\
553 \\
241 \\
194\end{array}$ & $\begin{array}{c}2.2 \\
54.8 \\
23.9 \\
19.2\end{array}$ & $\begin{array}{l}2.6 \\
60.3 \\
23.0 \\
14.0\end{array}$ & $\begin{array}{l}0.8^{\ddagger} \\
37.4 \\
26.4 \\
35.4\end{array}$ \\
\hline $\begin{array}{l}\text { Height-for-age }(Z \text {-score }) \\
\text { Low height }(\leq-1.0) \\
\text { Normal height }(\geq-0.9)\end{array}$ & $\begin{array}{c}19 \\
991\end{array}$ & $\begin{array}{c}1.9 \\
98.1\end{array}$ & $\begin{array}{c}2.0 \\
98.0\end{array}$ & $\begin{array}{c}1.6 \\
98.4\end{array}$ \\
\hline $\begin{array}{l}\text { Blood pressure } \\
\text { Hypertension } \\
\text { Hypertension - systolic } \\
\text { Hypertension - diastolic }\end{array}$ & $\begin{array}{l}246 \\
200 \\
109\end{array}$ & $\begin{array}{l}24.4 \\
19.8 \\
10.8\end{array}$ & & \\
\hline & Mean & SD & Mean & Mean \\
\hline Age (years) & 10.3 & 0.9 & 10.4 & 10.4 \\
\hline Weight (kg) & 40.4 & 10.8 & 39.9 & $45.0^{\ddagger}$ \\
\hline Height $(\mathrm{cm})$ & 142.8 & 8.8 & 142.3 & $144.2^{\ddagger}$ \\
\hline BMI $\left(\mathrm{kg} / \mathrm{m}^{2}\right)$ & 19.6 & 4.0 & 19.0 & $21.4^{\ddagger}$ \\
\hline Height (Z score) & -0.01 & 1.07 & -0.09 & $0.22^{\ddagger}$ \\
\hline BMI (Z score) & 0.76 & 1.29 & 0.58 & $1.33^{\ddagger}$ \\
\hline Systolic blood pressure $(\mathrm{mmHg})$ & 109.4 & 14.3 & & \\
\hline Diastolic blood pressure (mmHg) & 65.9 & 12.1 & & \\
\hline Heart rate (bpm) & 84.6 & 13.8 & 83.5 & $88.0^{\ddagger}$ \\
\hline
\end{tabular}

$\mathrm{n}$, frequency; SD, standard deviation; BMI, body mass index; bpm, beats per minute. ${ }^{\dagger} \mathrm{p}<0.01 ;{ }^{\ddagger} \mathrm{p}<0.001$.

In the statistical analysis, the sample size decreased for some variables because children were unwilling to participate (due to either lack of motivation or physical issues), schoolchildren did not have enough time, and reference standards for $\mathrm{VO}_{2 \max }$ were not available for children under 9 years of age (in this case, only the lap number was analyzed).

\section{Results}

The mean age of the schoolchildren was $10.3 \pm 0.9$ years and $56.8 \%$ were females (Table 1 ). A high percentage of participants $(43.0 \%)$ were overweight or obese and $1.9 \%$ showed low height-for-age. The prevalence of systolic hypertension, diastolic hypertension, and hypertension was $19.8 \%, 10.8 \%$, and $24.4 \%$, respectively. Schoolchildren with hypertension were heavier and taller, and their heart rate was higher compared with those without hypertension $(p<0.05)$.

Over two-thirds of the children showed low levels of fitness for push-ups, CRF, and curl-ups (Table 2). Around half of the participants showed low scores in the following tests: sit-and-reach, shoulder stretch, and trunk lift.

A higher probability of hypertension and isolated systolic hypertension was predicted for schoolchildren who needed to improve their CRF or upper body strength, and those with overweight or obesity (Table 3 ).

A higher frequency of poor CRF, abdominal strength and endurance, upper body strength, back and legs flexibility, and shoulder flexibility was observed in obese children (Table 4).

Children classified at health risk by their CRF showed a higher probability of hypertension (Table 5). The higher risk of hypertension persisted after adjusting the 
Table 2. Physical fitness of a sample of Mexican schoolchildren and differences by blood pressure

\begin{tabular}{|c|c|c|}
\hline & n & $\%$ \\
\hline $\begin{array}{l}\text { Cardiorespiratory fitness } \\
\text { Needs improvement-health risk } \\
\text { Needs improvement } \\
\text { Healthy zone }\end{array}$ & $\begin{array}{l}395 \\
161 \\
236\end{array}$ & $\begin{array}{l}50.0 \\
20.3 \\
29.7\end{array}$ \\
\hline $\begin{array}{l}\text { Curl-ups } \\
\text { Needs improvement } \\
\text { Healthy zone }\end{array}$ & $\begin{array}{l}620 \\
369\end{array}$ & $\begin{array}{l}62.7 \\
37.3\end{array}$ \\
\hline $\begin{array}{l}\text { Push-ups } \\
\text { Needs improvement } \\
\text { Healthy zone }\end{array}$ & $\begin{array}{l}750 \\
218\end{array}$ & $\begin{array}{l}77.5 \\
22.5\end{array}$ \\
\hline $\begin{array}{l}\text { Trunk lift } \\
\text { Needs improvement } \\
\text { Healthy zone }\end{array}$ & $\begin{array}{l}462 \\
546\end{array}$ & $\begin{array}{l}45.8 \\
54.2\end{array}$ \\
\hline $\begin{array}{l}\text { Sit and reach } \\
\text { Needs improvement } \\
\text { Healthy zone }\end{array}$ & $\begin{array}{l}557 \\
449\end{array}$ & $\begin{array}{l}55.4 \\
44.6\end{array}$ \\
\hline $\begin{array}{l}\text { Shoulder stretch } \\
\text { Needs improvement } \\
\text { Healthy zone }\end{array}$ & $\begin{array}{l}488 \\
515\end{array}$ & $\begin{array}{l}48.7 \\
51.3\end{array}$ \\
\hline & Mean & SD \\
\hline PACER test (laps number) & 14.7 & 8.5 \\
\hline $\mathrm{VO}_{2 \max }(\mathrm{ml} / \mathrm{kg} / \mathrm{min})$ & 37.6 & 5.0 \\
\hline Curl-ups (number) & 12.1 & 13.3 \\
\hline Push-ups (number) & 21.6 & 5.4 \\
\hline Trunk lift $(\mathrm{cm})$ & 4.1 & 5.8 \\
\hline Sit and reach (left leg) $(\mathrm{cm})$ & 22.7 & 7.5 \\
\hline Sit and reach (right leg) $(\mathrm{cm})$ & 22.5 & 7.6 \\
\hline
\end{tabular}

$\mathrm{n}$, frequency; SD, standard deviation; PACER, progressive aerobic cardiovascular endurance run; $\mathrm{VO}_{2 \max }$, predicted maximal aerobic capacity.

model by age and sex. However, after including BMI-for-age, the differences disappeared. In model B, only BMl-for-age was associated with hypertension.

A higher risk of hypertension was estimated for children who needed to improve their upper body strength as well (Table 5). These associations remained after adjusting the model by age and sex. In contrast, after including BMI-for-age, the differences were not statistically significant. In model B, only BMI-for-age was associated with hypertension as well.

\section{Discussion}

The purpose of this study was to determine whether the relationship of fitness with blood pressure in Mexican schoolchildren was independent of body mass. In this
Mexican children sample, poor CRF and upper body strength were related to a higher risk of systolic hypertension. However, this relationship disappeared after adjusting for BMI. In addition, higher levels of BMI were negatively correlated with most fitness levels.

Except for the trunk lift test, children with overweight or obesity performed poorly in the fitness tests. Although the association of flexibility with BMI has been inconsistent ${ }^{21,22}$, a negative correlation of $\mathrm{BMI}$ with $\mathrm{CRF}^{7,8,21,23}$ and muscular strength and endurance $\mathrm{e}^{21,24,25}$ has been systematically observed in pediatric populations. Some of the characteristics of children with overweight or obesity, such as a tendency to a more sedentary lifestyle ${ }^{26}$, to experience fatigue faster ${ }^{27}$, and to present lower performance in aerobic tests ${ }^{28}$ can explain these differences. Furthermore, they perceive more difficulty with several activities of daily living ${ }^{29}$, and these difficulties may limit their performance during fitness tests because they face unfamiliar situations such as effort exertion, muscle fatigue, and discomfort.

Unexpectedly, Mexican children with normal weight showed a higher probability of poor performance in the trunk lift test than those with overweight or obesity. In two samples of American children, BMI was not associated with performance in this test ${ }^{21,30}$. One possible explanation is that trunk extensor strength is influenced by body size, i.e., trunk weight serves as "natural" resistance. Therefore, heavier subjects may develop more strength in this region. However, this association could be spurious and adjustments for potential confounders are needed in future research.

In the present sample, poor CRF was associated with a higher risk of hypertension, but this association disappeared after adjusting for BMI. In previous studies, a negative association with CRF has been reported ${ }^{3-5,31}$. However, the potential role of body mass or adiposity was not taken into account. In contrast, in one study ${ }^{5}$, this association disappeared after adjusting for BMI, consistent with these results. These findings could suggest that rather than having a direct and independent effect on blood pressure, CRF is a mediating variable between body weight and blood pressure. However, other mediating variables could exist, as the relationship between BMI and blood pressure remained after adjusting for fitness.

In this Mexican children sample, upper body strength was negatively related to blood pressure; however, this association disappeared after adjusting for BMI. This relationship may emerge clearly during adolescence, as shown in a study with Spanish schoolchildren ${ }^{25}$, but this relationship disappeared after adjusting for BMI (similar results as obtained in this research). In adolescents, 
Table 3. Prevalence of hypertension according to fitness and body mass index-for-age in a sample of Mexican schoolchildren

\begin{tabular}{|c|c|c|c|}
\hline & $\begin{array}{c}\text { Systolic or diastolic hypertension or } \\
\text { both }\end{array}$ & $\begin{array}{l}\text { Isolated systolic } \\
\text { hypertension }\end{array}$ & $\begin{array}{l}\text { Isolated diastolic } \\
\text { hypertension }\end{array}$ \\
\hline$n=1010$ & $\%$ & $\%$ & $\%$ \\
\hline $\begin{array}{l}\text { Cardiorespiratory fitness } \\
\text { Needs improvement-health risk } \\
\text { Needs improvement } \\
\text { Healthy zone }\end{array}$ & $\begin{array}{l}29.1^{*} \\
21.7 \\
20.3\end{array}$ & $\begin{array}{r}24.3^{*} \\
19.3 \\
15.7\end{array}$ & $\begin{array}{l}10.6 \\
8.7 \\
9.7\end{array}$ \\
\hline $\begin{array}{l}\text { Curl-ups } \\
\text { Needs improvement } \\
\text { Healthy zone }\end{array}$ & $\begin{array}{l}24.8 \\
23.6\end{array}$ & $\begin{array}{l}20.3 \\
18.7\end{array}$ & $\begin{array}{l}11.6 \\
10.0\end{array}$ \\
\hline $\begin{array}{l}\text { Push-ups } \\
\text { Needs improvement } \\
\text { Healthy zone }\end{array}$ & $\begin{array}{c}26.1^{*} \\
18.8\end{array}$ & $\begin{array}{r}21.5^{*} \\
14.2\end{array}$ & $\begin{array}{c}11.3 \\
9.6\end{array}$ \\
\hline $\begin{array}{l}\text { Trunk lift } \\
\text { Needs improvement } \\
\text { Healthy zone }\end{array}$ & $\begin{array}{l}22.9 \\
25.6\end{array}$ & $\begin{array}{l}18.4 \\
21.1\end{array}$ & $\begin{array}{l}10.0 \\
11.5\end{array}$ \\
\hline $\begin{array}{l}\text { Sit and reach } \\
\text { Needs improvement } \\
\text { Healthy zone }\end{array}$ & $\begin{array}{l}23.7 \\
25.2\end{array}$ & $\begin{array}{l}18.5 \\
21.4\end{array}$ & $\begin{array}{c}9.7 \\
12.2\end{array}$ \\
\hline $\begin{array}{l}\text { Shoulder stretch } \\
\text { Needs improvement } \\
\text { Healthy zone }\end{array}$ & $\begin{array}{l}24.0 \\
24.7\end{array}$ & $\begin{array}{l}19.7 \\
19.8\end{array}$ & $\begin{array}{c}9.6 \\
11.8\end{array}$ \\
\hline $\begin{array}{l}\text { Body mass index-for-age } \\
\text { Normal } \\
\text { Overweight } \\
\text { Obesity }\end{array}$ & $\begin{array}{l}16.3^{\ddagger} \\
27.0 \\
44.8\end{array}$ & $\begin{array}{l}12.2^{\ddagger} \\
23.2 \\
38.1\end{array}$ & $\begin{array}{c}9.4 \\
10.8 \\
14.9\end{array}$ \\
\hline
\end{tabular}

Comparisons according to fitness categories (e.g., needs improvement vs. healthy zone) and to body mass index (e.g., normal vs. obesity). ${ }^{*} p<0.05 ;{ }^{\ddagger} p<0.001$.

Table 4. Association of body mass index-for-age with low fitness in a sample of Mexican schoolchildren

\begin{tabular}{|l|c|c|c|c|}
\hline & Normal (\%) & Overweight (\%) & Obesity (\%) & p \\
\hline Subjects that need to improve or with health risk & & & & \\
$\quad$ CRF-health risk & 32.1 & 60.6 & 7.7 & \\
CRF-need improvement & 24.5 & 20.7 & 76.1 & $\ddagger$ \\
Curl-ups & 57.5 & 64.4 & 94.0 & $\ddagger$ \\
Push-ups & 69.3 & 83.8 & 36.8 & $\ddagger$ \\
Trunk lifts & 50.9 & 41.1 & 64.4 & $*$ \\
Sit and reach & 53.2 & 53.3 & 71.6 & $\ddagger$ \\
Shoulder stretch & 40.7 & 49.4 & & $\ddagger$ \\
\hline
\end{tabular}

CRF, cardiorespiratory fitness.

${ }^{*} p<0.05 ;{ }^{\dagger} p<0.01 ;{ }^{\ddagger} p<0.001$.

weak to moderate negative correlations were observed for muscle fitness and CRF with cardiovascular risk factors and this correlation was stronger between systolic blood pressure and muscle fitness than with CRF. This relationship remained after stratifying by $\mathrm{BMI}^{32}$. In Norwegian children and adolescents ${ }^{31}$ and Spanish adolescents ${ }^{33}$, muscle fitness was negatively related to cardiometabolic risk, independent of CRF. Unfortunately, in both studies, adjustment for body weight was not performed. Although strength training could lower blood pressure ${ }^{34}$, the evidence regarding the association of muscle fitness with blood pressure for children is insufficient and inconclusive.

The strengths of this study include the sample size and the heterogeneity of the participants, as they were recruited from different schools in Mexico City. However, 
Table 5. Logistic regression models having hypertension as an outcome and cardiorespiratory fitness and push-ups test as exposures

\begin{tabular}{|c|c|c|c|c|}
\hline & \multicolumn{2}{|c|}{ Outcome: hypertension exposure: CRF'1 } & \multicolumn{2}{|c|}{ Outcome: hypertension exposure: push-ups ${ }^{2}$} \\
\hline & OR & CI $95 \%$ & $\mathbf{O R}$ & CI $95 \%$ \\
\hline \multicolumn{5}{|l|}{ Crude model } \\
\hline $\begin{array}{l}\text { Physical fitness } \\
\text { Healthy zone } \\
\text { Needs improvement } \\
\text { Needs improvement-health risk }\end{array}$ & $\begin{array}{l}\text { Reference } \\
1.09 \\
1.61\end{array}$ & $\begin{array}{l}0.66-1.77 \\
1.09-2.36\end{array}$ & $\begin{array}{c}\text { Reference } \\
1.53\end{array}$ & $1.05-2.22$ \\
\hline \multicolumn{5}{|l|}{ Adjusted model $A^{*}$} \\
\hline $\begin{array}{l}\text { Physical fitness } \\
\text { Healthy zone } \\
\text { Needs improvement } \\
\text { Needs improvement-health risk }\end{array}$ & $\begin{array}{l}\text { Reference } \\
1.28 \\
2.05\end{array}$ & $\begin{array}{l}0.77-2.12 \\
1.33-3.15\end{array}$ & $\begin{array}{c}\text { Reference } \\
1.57\end{array}$ & $1.07-2.29$ \\
\hline \multicolumn{5}{|l|}{ Adjusted model $B^{* *}$} \\
\hline $\begin{array}{l}\text { Physical fitness } \\
\text { Healthy zone } \\
\text { Needs improvement } \\
\text { Needs improvement-health risk }\end{array}$ & $\begin{array}{l}\text { Reference } \\
0.94 \\
0.87\end{array}$ & $\begin{array}{l}0.56-1.59 \\
0.52-1.47\end{array}$ & $\begin{array}{c}\text { Reference } \\
1.12\end{array}$ & $0.75-1.68$ \\
\hline $\begin{array}{l}\text { Body mass index-for-age } \\
\text { Normal } \\
\text { Overweight } \\
\text { Obesity }\end{array}$ & $\begin{array}{c}\text { Reference } \\
1.88 \\
4.48\end{array}$ & $\begin{array}{l}1.23-2.89 \\
2.71-7.39\end{array}$ & $\begin{array}{c}\text { Reference } \\
1.80 \\
3.59\end{array}$ & $\begin{array}{l}1.25-2.60 \\
2.44-5.28\end{array}$ \\
\hline
\end{tabular}

Sample sizes: 1792 and ${ }^{2} 968$. CRF: cardiorespiratory fitness; OR: odds ratio; Cl 95\%: 95\% confidence intervals; Reference: group of reference.

${ }^{*}$ Adjusted by sex and age; ${ }^{* *}$ Adjusted by sex, age, and body mass index-for-age.

the results should be interpreted with caution considering the limitations of the design. Furthermore, the use of automatic blood pressure monitors - which are not the recommended method because, in older people, they provide underestimated measures - should be considered ${ }^{35}$. However, the validity of these devices has been tested ${ }^{16}$ and they have advantages, such as the elimination of the observer error, the minimizing of the white coat effect, and the opportunity to reduce costs associated with the training of observers ${ }^{35}$.

The cross-sectional design of the study precludes from making causal conclusions and convenience sampling limits the possibility of extrapolation. In the case of the logistic regression model with CRF as exposure, the lack of reference to classify younger children yields that more than $20 \%$ of the data of the participants were excluded, which reduces the validity of the model. Besides, the models were not adjusted by sexual maturity, which can affect physical fitness.

In summary, in this group of Mexican children, low CRF and muscle fitness were negatively related to the risk of hypertension. However, these associations disappeared when controlling for BMI. With one exception ${ }^{5}$, most studies ${ }^{3,4}$ have not accounted for the potential role of BMI as a confounding variable in the relationship between fitness and blood pressure. This confounding effect can explain the discrepancies between the present results and those previously reported.

\section{Ethical disclosures}

Protection of human and animal subjects. The authors declare that no experiments were performed on humans or animals for this study.

Confidentiality of data. The authors declare that they have followed the protocols of their work center on the publication of patient data.

Right to privacy and informed consent. The authors declare that no patient data appear in this article.

\section{Conflicts of interest}

The authors declare that they have no conflicts of interest.

\section{Funding}

None. 


\section{References}

1. Chen X, Wang Y. Tracking of blood pressure from childhood to adulthood: a systematic review and meta-regression analysis. Circulation. 2008; 117:3171-80.

2. Rapsomaniki E, Timmis A, George J, Pujades-Rodriguez M, Shah AD, Denaxas S, et al. Blood pressure and incidence of twelve cardiovascular diseases: lifetime risks, healthy life-years lost, and age-specific associations in 1.25 million people. Lancet. 2014;383:1899-911.

3. Ogunleye AA, Sandercock GR, Voss C, Eisenmann JC, Reed K. Prevalence of elevated mean arterial pressure and how fitness moderates its association with BMI in youth. Public Health Nutr. 2013;16:2046-54.

4. Anderssen SA, Cooper AR, Riddoch C, Sardinha LB, Harro M, Brage S, et al. Low cardiorespiratory fitness is a strong predictor for clustering of cardiovascular disease risk factors in children independent of country, age and sex. Eur J Cardiovasc Prev Rehabil. 2007;14:526-31.

5. Díez-Fernández A, Sánchez-López M, Mora-Rodríguez R, Notario-Pacheco B, Torrijos-Niño C, Martínez-Vizcaíno V. Obesity as a mediator of the influence of cardiorespiratory fitness on cardiometabolic risk: a mediation analysis. Diabetes Care. 2014:37:855-62.

6. Ruiz JR, Castro-Piñero J, Artero EG, Ortega FB, Sjöström M, Suni J, et al. Predictive validity of health-related fitness in youth: a systematic review. Br J Sports Med. 2009;43:909-23.

7. Galavíz KI, Tremblay MS, Colley R, Jáuregui E, López y Taylor J, Janssen I. Associations between physical activity, cardiorespiratory fitness, and obesity in Mexican children. Salud Publica Mex. 2012;54:463-9.

8. Minasian V, Marandi SM, Kelishadi R, Abolhassani H. Correlation between aerobic fitness and body composition in middle school students. Int J Prev Med. 2014;5:S102-7.

9. Lurbe E, Alvarez V, Redon J. Obesity, body fat distribution, and ambulatory blood pressure in children and adolescents. J Clin Hypertens (Greenwich). 2001;3:362-7.

10. He Q, Ding ZY, Fong DY, Karlberg J. Blood pressure is associated with body mass index in both normal and obese children. Hypertension. 2000;36:165-70.

11. Epidat: programa Para Análisis Epidemiolóxico de Datos. Versión 4.2 Xullo 2016 [Computer Program]. España: Consellería de Sanidade, Xunta de Galicia, España. Colombia: Organización Panamericana da saúde (OPS-OMS); Universidade CES; 2016.

12. Colín-Ramírez E, Castillo-Martínez L, Orea-Tejeda A, Villa Romero AR, Vergara Castañeda A, Asensio Lafuente E. Waist circumference and fat intake are associated with high blood pressure in Mexican children aged 8 to 10 years. J Am Diet Assoc. 2009;109:996-1003.

13. Plowman SA, Meredith MD. Fitnessgram/Activitygram: Reference Guide. Dallas, Texas: The Cooper Institute; 2013.

14. Mahar MT, Guerieri AM, Hanna MS, Kemble CD. Estimation of aerobic fitness from 20-m multistage shuttle run test performance. Am J Prev Med. 2011;41:S117-23.

15. California Department of Education. FITNESSGRAM: healthy Fitness Zone Charts. Sacramento, CA: California Department of Education; 2015

16. Stergiou GS, Yiannes NG, Rarra VC. Validation of the Omron 705 IT oscillometric device for home blood pressure measurement in children and adolescents: the Arsakion School study. Blood Press Monit. 2006;11:229-34.

17. National High Blood Pressure Education Program Working Group on High Blood Pressure in Children and Adolescents. The fourth report on the diagnosis, evaluation, and treatment of high blood pressure in children and adolescents. Pediatrics. 2004;114:555-76.

18. Kuczmarski RJ, Ogden CL, Guo SS, Grummer-Strawn LM, Flegal KM, Mei Z, et al. 2000 CDC growth charts for the United States: methods and development. Vital Health Stat 11. 2002;264:1-90.
19. Lohmann TG, Roche AF, Martorell R. Anthropometric Standardization Reference Manual. Champaign, Illinois: Human Kinetics Books; 1988.

20. de Onis M, Onyango AW, Borghi E, Siyam A, Nishida C, Siekmann J. Development of a WHO growth reference for school-aged children and adolescents. Bull World Health Organ. 2007;85:660-7.

21. Joshi $P$, Bryan $C$, Howat $H$. Relationship of body mass index and fitness levels among schoolchildren. J Strength Cond Res. 2012;26:1006-14.

22. Committee on Fitness Measures and Health Outcomes in Youth; Food and Nutrition Board; Institute of Medicine. Health-related fitness measures for youth: flexibility. In: Pate R, Oria M, Pillsbury L, editors. Fitness Measures and Health Outcomes in Youth. Washington, DC: National Academies Press (US); 2012. p. 187-206.

23. Tovar G, Poveda JG, Pinilla MI, Lobelo F. Relationship between overweight, physical activity and physical fitness in school-aged boys in Bogotá Colombia. Arch Latinoam Nutr. 2008:58:265-73.

24. Rodríguez Valero FJ, Gualteros JA, Torres JA, Umbarila Espinosa LM, Ramírez-Velez R. Association between muscular fitness and physical health status among children and adolescents from Bogotá, Colombia. Nutr Hosp. 2015;32:1559-66.

25. Díez-Fernández A, Sánchez-López M, Gulías-González R, Notario-Pacheco B, Cañete García-Prieto J, Arias-Palencia N, et al. BMI as a mediator of the relationship between muscular fitness and cardiometabolic risk in children: a mediation analysis. PLoS One. 2015;10:e0116506.

26. Page A, Cooper AR, Stamatakis E, Foster LJ, Crowne EC, Sabin M, et al. Physical activity patterns in nonobese and obese children assessed using minute-by-minute accelerometry. Int J Obes (Lond). 2005;29:1070-6.

27. Garcia-Vicencio S, Martin V, Kluka V, Cardenoux C, Jegu AG, Fourot AV, et al. Obesity-related differences in neuromuscular fatigue in adolescent girls. Eur J Appl Physiol. 2015;115:2421-32.

28. Moran CA, Peccin MS, Bombig MT, Pereira SA, Dal Corso S. Performance and reproducibility on shuttle run test between obese and non-obese children: a cross-sectional study. BMC Pediatr. 2017;17:68.

29. Valerio G, Gallarato V, D'Amico O, Sticco M, Tortorelli P, Zito E, et al. Perceived difficulty with physical tasks, lifestyle, and physical performance in obese children. Biomed Res Int. 2014;2014:735764.

30. Shriver LH, Harrist AW, Hubbs-Tait L, Topham G, Page M, Barrett A. Weight status, physical activity, and fitness among third-grade rural children. J Sch Health. 2011:81:536-44.

31. Steene-Johannessen J, Anderssen SA, Kolle E, Andersen LB. Low muscle fitness is associated with metabolic risk in youth. Med Sci Sports Exerc. 2009;41:1361-7.

32. Artero EG, Ruiz JR, Ortega FB, España-Romero V, Vicente-Rodríguez G, Molnar D, et al. Muscular and cardiorespiratory fitness are independently associated with metabolic risk in adolescents: the HELENA study. Pediatr Diabetes. 2011;12:704-12.

33. García-Artero E, Ortega FB, Ruiz JR, Mesa JL, Delgado M, González-Gross M, et al. Lipid and metabolic profiles in adolescents are affected more by physical fitness than physical activity (AVENA study). Rev Esp Cardiol. 2007;60:581-8.

34. Brook RD, Appel LJ, Rubenfire M, Ogedegbe G, Bisognano JD, Elliott WJ, et al. Beyond medications and diet: alternative approaches to lowering blood pressure: a scientific statement from the American heart association. Hypertension. 2013;61:1360-83.

35. Pickering TG, Hall JE, Appel LJ, Falkner BE, Graves J, Hill MN, et al Recommendations for blood pressure measurement in humans and experimental animals. Part 1. Blood pressure measurement in humans: a statement for professionals from the subcommittee of professional and public education of the American heart association council on high blood pressure research. Circulation. 2005;111:697-716. 